\title{
MATEMATIKAI PSZICHOLÓGIA / PSZICHOLÓGIAI STATISZTIKA / MÉRÉS
}

\author{
VARGHA ANDRÁS \\ Károli Gáspár Református Egyetem, Budapest, Magyarország \\ ELTE Pedagógiai és Pszichológiai Kar, Budapest, Magyarország \\ E-mail: vargha.andras@ppk.elte.hu
}

Benyújtva: 2021. július 21. - Elfogadva: 2021. július 25.

\begin{abstract}
A pszichológia matematikai alapokon nyugvó fejlesztése Magyarországon az elmúlt 30 évben elsôsorban három intézményhez köthetô, ezek: a DE, az ELTE és a KRE Pszichológiai Intézete. A matematikai pszichológia hazai központja a DE Pszichológiai Intézete, ahol az elmúlt évtizedekben jelentốs eredményeket értek el a méréselmélet és a strukturális egyenletek modelljeivel kapcsolatban. A pszichológiai statisztikán belül figyelemre méltó, nemzetközi mércével mérve is kiemelkedô hazai eredmények születtek - több kutatóhelyhez kötődve - a statisztikai próbák kritikája, a bayesi statisztika, a paraméteres próbák és robusztus változataik megbizhatósága, a rangsorolásos eljárások, az idősorelemzés, valamint a klasszifikációs eljárások témaköreiben. Az elmúlt 30 évben a mérés, pszichometria témakörében is születtek kiemelkedô hazai eredmények.
\end{abstract}

Kulcsszavak: matematikai pszichológia, pszichológiai statisztika, méréselmélet, pszichometria

A pszichológia matematikai alapokon nyugvó fejlesztése Magyarországon három intézményhez köthetô, ezek: a DE, az ELTE és a KRE Pszichológiai Intézete. Az e témakörbe tartozó kutatásokat tömören az alábbiak szerint foglaljuk össze három részben.

\section{MATEMATIKAI PSZICHOLÓGIA}

A matematikai pszichológia hazai központja a DE Pszichológiai Intézete, ahol az elmúlt évtizedekben jelentôs eredményeket értek el ezen a téren. Ezek közül a méréselmélet matematikai modelljeivel kapcsolatban megemlítendô Hunyady és Münnich (1995), Molenaar és Münnich (1993), Münnich (1993, 1994, 2000), Münnich, Maksa és Mokken (1999, 2000), Münnich, Mokken és Saris (2004). Társas ítéletalkotások so- 
rán kitüntetett szerepe van a referenciapontoknak, melyek a válaszokat determinálják. Münnich Ákos (2006) erre a méréselméleti jelenségre matematikailag is nóvumnak számító modelleket adott meg. A strukturális egyenletek modelljeivel kapcsolatban figyelemre méltó eredményeket ért el továbbá Münnich és Hidegkuti (2012).

\section{PSZICHOLÓGIAI STATISZTIKA}

\section{A statisztikai próbák kritikája, bayesi statisztika}

Az utóbbi idôben számos kritika érte a pszichológia módszertanában a hagyományos hipotézisvizsgálatokat. Sokan a statisztikai próbák helyett inkább a hatásmértékek és az intervallumbecslések használatát javasolják, köztük magyar pszichológusok is (Szúcs és Ioannidis, 2017; Vargha, 2016a). Mások a bayesi statisztika gyakoribb alkalmazásában látják a probléma megoldását. Aczél Balázs és munkatársai neves angol nyelvú folyóiratokban publikálták a bayesi következtetésekkel és a Bayes-faktorokkal kapcsolatos, komoly nemzetközi visszhangot kiváltó fejtegetéseiket (Aczél, Pálfi és Szászi, 2017; Aczél és mtsai, 2020).

\section{Paraméteres próbák megbizhatósága és robusztus változataik}

A pszichológiai kutatások tekintélyes részében átlagok segítségével hasonlítunk össze helyzeteket és csoportokat, t-próbák és varianciaanalízis (VA) segítségével. E statisztikai próbák alkalmazási feltételei (normalitás és szóráshomogenitás) gyakran nem teljesülnek, ami megkérdőjelezheti alkalmazásuk érvényességét és megbízhatóságát. E problémák súlyosságát és alternatív, robusztus próbák alkalmazhatóságának lehetôségét vizsgálta a $t$-próbákkal kapcsolatban Vargha (2001, 2003), dichotóm változókkal végzett VA-kkal kapcsolatban pedig Vargha (1993).

Ha a független mintás VA szempontváltozóit folytonos változók dichotomizálásával képezzük, joggal gondolhatunk arra, hogy a dichotomizálás információveszteséggel jár, s ezért a VA-ban nehezített lesz e szempontok hatásainak kimutatása. Vargha, Rudas, Delaney és Maxwell (1996) elemzései azonban arra hívják fel a figyelmet, hogy ez nincs mindig így, a dichotomizálás nem minden esetben jár információveszteséggel. Erre akkor számíthatunk, ha a dichotomizált szempontváltozók szoros korrelációban vannak. Folytonos változók két vagy több kategóriára való osztására sikeresen alkalmazható az osztópontelemzés (Vargha és Bergman, 2012; illetve Vargha, 2020, 5. fejezet).

Robusztus változatnak tekinthetố az a megoldás is, amikor adott statisztikai módszert más matematikai eljárásokkal erôsítünk meg, illetve dolgozunk fel. Erre jó példa lehet Niroomand, Takács és Vizvári (2011) munkája, melyben a többdimenziós skálázás (MDS) módszerét optimalizálási feladatként írják fel és oldják meg, tetszôleges távolságok definiálásával általánosítva a feladatot. 
Idesorolható T. Kárász Judit (2019a, 2019b) munkája is, melynek keretében ismerteti, hogy az OECD PISA-felmérések metodikája miként került átültetésre bootstrap és BRR jackknife módszerek kombinálásával az Országos kompetenciamérésben. E mérésmetodika az adott paraméterek konfidenciaintervallumának becslési eljárásaira ad szimulációs megoldásokat, jellemzôen nagy - akár százezer feletti - minták esetére is.

\section{Korreláció, regresszió}

A normalitás sérülése olykor komoly gondot okozhat korrelációs és regressziós elemzések során is. A regresszióval kapcsolatban ezt boncolgatja Münnich, Nagy és Pénzes (2004) tanulmánya. Különösen problémás a helyzet a parciális korrelációs együttható esetén, melynek értelmezése erôsen függ a normalitás fennállásától. Ha ugyanis a vizsgált változók együttes eloszlása többdimenziós normális, akkor a parciális korrelációs együttható egyben feltételes korrelációként is értelmezhető, mely azt méri, hogy mekkora a korreláció két ( $X$ és $Y$ ) változó között, ha rögzített szinten tartjuk egy vagy több - kiszúrendô hatású - kvantitatív változó értékszintjét. Vargha (2011), illetve Vargha, Bergman és Delaney (2013) vizsgálatai azonban arra hívják fel a figyelmet, hogy a többdimenziós normalitás sérülése esetén a parciális korreláció és a feltételes korreláció durva mértékben is eltérhet egymástól (pl. elképzelhetô, hogy az elôbbi 0,7-nél is nagyobb, miközben az utóbbi -0,7-nél is kisebb).

Vargha és munkatársai (1996) fentebb már említett vizsgálatai arra is felhívták a figyelmet, hogy dichotomizált folytonos változók között csak akkor csökken érdemben a mért kapcsolat szorossága, ha a folytonos változók között mért Pearson-korreláció alacsony vagy mérsékelt nagyságszintû.

\section{Rangsorolásos eljárások}

Különbözô csoportok nagyságszintjének összehasonlítására a normalitás sérülése esetén a hagyományos paraméteres statisztikai próbák (pl. kétmintás t-próba vagy VA) helyett gyakran ajánlják rangsorolásos eljárások (pl. Mann-Whitney- vagy KruskalWallis-próba) alkalmazását. Ez esetben komoly problémát jelent, hogy éppen a normalitás sérülése esetén a paraméteres és a rangsorolásos próbák nullhipotézise nem feltétlenül egyezik meg, vagyis mást tesztelünk az egyikkel és mást a másikkal. Vargha (1999, 2000), illetve Vargha és Delaney (2000) kimutatta, hogy két minta hagyományos rangsorolásos összehasonlítása esetén az adekvát nullhipotézis a minták által képviselt eloszlások sztochasztikus egyenlôsége, melynek tesztelésére gyakran robusztus rangsorolásos technikák alkalmazása indokolt (Delaney és Vargha, 2002). Kettônél több minta rangsorolásos összehasonlítása esetén pedig az adekvát nullhipotézis a minták által képviselt eloszlások sztochasztikus homogenitása (vö. Vargha és Delaney, 1998; illetve Vargha, 2002 és 2005). Jelentôs újdonság e téren a kétszempontos sztochasztikus összehasonlítás fogalmának és tesztelési módjának bevezetése (vö. Vargha, 2004, ill. 2020, 4.3. alfejezet). 


\section{Többváltozós statisztika}

A többváltozós statisztika az elmúlt évtizedekben forradalmi fejlődésen ment át, és ez nagy hatással volt a pszichológiai kutatások módszertanára is. Ehhez a fejlôdéshez több területen magyar pszichológus kutatók is hozzájárultak.

Az idôsorelemzésben Máth és munkatársai publikáltak figyelemre méltó eredményeket (Máth, 1996; Terdik és Máth, 1998). A loglineáris modellek vizsgálatához Máth (2004), a logisztikus regresszió vizsgálatához pedig Balázs, Hidegkuti és De Boeck járultak hozzá fontos részletekkel.

A klasszifikációs eljárásokkal kapcsolatban a hazai kutatók számos területen gazdagították a témakör tudományos eredményeit. Surányi, Babocsay, Takács és Vargha (2011), illetve Bergman, Vargha és Kövi (2017) a klaszteranalízis új módszereinek használatára mutattak rá a személyorientált pszichológiában, Vargha és Borbély (2017) pedig a kétnyelvúség és az etnikai identitás kutatásában. A klaszteranalízis eredményének kiértékelésében fontos szerepe van a különféle adekvációs mutatóknak. Ezek tekintetében jelentôs eredményeket értek el a hazai kutatók (lásd Takács, Makrai és Vargha, 2015; Vargha, Bergman és Takács, 2016; Vargha és Bergman, 2019).

A KRE Pszichológiai Intézete és az ANIMAGROUP cégcsoport közös Hazugságkutató Múhelyének egyik kutatásában a hazugságok típusainak azonosítására dolgoztak ki újfajta kombinált eljárást a VA és a klaszterezés alapgondolatainak házasításával (Kis, Takács, Liberman és Benczúr, 2017a; Kis és mtsai, 2017b; Czabán és mtsai, 2017a, 2017b; Madzin és mtsai, 2017a, 2017b; Takács, Kis, Makrai és Liberman, 2017).

A többváltozós statisztika hazai alkalmazását nagymértékben elôsegítették az e témában az utóbbi időkben megjelent elméleti összefoglaló és az R, SPSS, CogStat, illetve ROPstat szoftverhasználatot elôsegítô publikációk (Krajcsi, 2020; Münnich, Nagy és Abari, 2006; Ketskeméty, Izsó és Könyves Tóth, 2011; Vargha, 2016b, 2019, 2020, 2021; Vargha, Torma és Bergman, 2015).

\section{MÉRÉS, PSZICHOMETRIA}

Nagybányai Nagy (2014) új pszichometriai fejlesztési lehetôségeket talált az online tesztelésben. Jelenleg megjelenés alatt van a KRE Pszichológiai Intézetének Kompetenciamérés kutatócsoportja által kidolgozott optimalizálási formulája, melynek segítségével T. Kárász Judit és munkatársai meghatározták, hogy egy papír-ceruza alapú teszt esetében elért mérési pontosságot milyen hosszú adaptív teszt segítségével lehet a legjobb esetben elérni (T. Kárász és Takács, 2020).

Balázs, Csízik, Hôgye-Nagy és Münnich (2009, 2012) a páros összehasonlítás Thurstone-féle módszerének pszichológiai alkalmazásában, Rijmen, Tuerlinckx, Meulders, Smits és Balázs (2005, 2006) pedig a modern tesztelmélet kevert modelljeinek becslésében értek el figyelemre méltó eredményeket.

A pszichometria hazai alkalmazását is jelentôs mértékben elősegítették az e témában az utóbbi idôkben megjelent összefoglaló múvek (pl. Horváth, 1997; Rózsa, Nagybányai Nagy, Oláh, 2006; Hidegkuti és Balázs, 2015; Münnich, Balázs, Fedor és Hidegkuti, 2001; Vargha, 1994). 


\section{IRODALOM}

Aczél, B., Pálfi, B., \& Szászi, B. (2017). Estimating the evidential value of significant results in psychological science. PLoS One, 12(8), e0182651.

Aczél, B., Hoekstra, R., Gelman, A., Wagenmakers, E. J., Klugkist, I. G., Rouder, J. N., et al. (2020). Discussion points for Bayesian inference. Nature Human Behaviour, 4(6), 561-563.

Balázs, K., Csízik, T., Hốgye-Nagy, Á., \& Münnich, Á. (2009). A páros összehasonlítás Thurstoneféle módszerének alkalmazása a pszichológiában I., Alkalmazott Pszichológia, 11(1-2), 127146.

Balázs, K., Csízik, T., Hôgye-Nagy, Á., \& Münnich, Á. (2012). A páros összehasonlítás Thurstoneféle módszerének alkalmazása a pszichológiában II. Alkalmazott Pszichológia, 14(1), 45-63.

Bergman, L. R., Vargha, A., \& Kövi, Z. (2017). Revitalizing the typological approach: Some methods for finding types. Journal for Person-Oriented Research, 3(1), 49-62.

Czabán, Cs., Alpek, A., Bártfai, A., Kertesy, A., Iványuk, Á., Benczúr, L., Takács, Sz., \& Kis, Gy. (2017a). A vallomások igazságtartamát meghamisítók típusai és vizsgálatuk kihallgatási helyzetben - 1. rész, a meghamisító. Psychologia Hungarica Caroliensis, 4(2), 27-35.

Czabán, Cs., Alpek, A., Bártfai, A., Kertesy, A., Iványuk, Á., Benczúr, L., Takács, Sz., \& Kis, Gy. (2017b). A vallomások igazságtartamát meghamisítók típusai és vizsgálatuk kihallgatási helyzetben - 2. rész, az elhallgató. Psychologia Hungarica Caroliensis, 4(2), 36-43.

Delaney, H. D., \& Vargha, A. (2002). Comparing several robust tests of stochastic equality with ordinally scaled variables and small to moderate sized samples. Psychological Methods, 7(4), 485-503.

Hidegkuti, I., \& Balázs, K. (2015). Tesztelmélet. In Balázs, K., Kovács J., \& Münnich, Á. (Eds), Pszichológiai Módszertani Tanulmányok (pp. 65-95). Debrecen: Debreceni Egyetemi Kiadó,.

Horváth, Gy. (1997). A modern tesztmodellek alkalmazása. Budapest: Akadémiai Kiadó.

Hunyady, G., \& Münnich, A. (1995). A modified True Score MTMM model for analysing stereotype effects on characterizations of nations. In Saris, W. E., \& Münnich, Á. (Eds), The Multitrait-Multimethod Approach to Evaluate Measurement Instruments (175-176). Budapest: Eötvös Kiadó.

Ketskeméty, L., Izsó, L., \& Könyves Tóth, E. (2011). Bevezetés az IBM SPSS Statistics programrendszerbe: Módszertani útmutató és feladatgyújtemény statisztikai elemzésekhez. Harmadik, javított, átdolgozott és kibóvített kiadás. Budapest: Arteria Stúdió.

Kis, Gy., Füzes, N., Mátay, G., Pusker, M., Makrai, B., Czabán, Cs., \& Takács, Sz. (2017b). Újfajta szivárgások leírása a vallomások során, videófelvételek elemzésével. Psychologia Hungarica Caroliensis, 4(2), 79-93.

Kis, Gy., Takács, Sz., Liberman, A., \& Benczúr, L. (2017a). A megtévesztés tipológiája - összefoglaló tanulmány. Psychologia Hungarica Caroliensis, 4(2), 7-26.

Krajcsi, A. (2020). Introduction to statistics with CogStat. Budapest: Eötvös Loránd University, Faculty of Education and Psychology. Letöltve: 2021. 11. 11-én: https://edit.elte.hu/xmlui/ handle/10831/49337

Madzin, A., Alpek, A., Bártfai, A., Kertesy, A., Iványuk, Á., Benczúr, L., Takács, Sz., \& Kis, Gy. (2017a). A vallomások igazságtartamát meghamisítók típusai és vizsgálatuk kihallgatási helyzetben - 3. rész, az eltitkoló. Psychologia Hungarica Caroliensis, 4(2), 44-51.

Madzin, A., Alpek, A., Bártfai, A., Kertesy, A., Iványuk, Á., Benczúr, L., Takács, Sz., \& Kis, Gy. (2017b). A vallomások igazságtartamát meghamisítók típusai és vizsgálatuk kihallgatási helyzetben - 4. rész, a patetikus. Psychologia Hungarica Caroliensis, 4(2), 52-59.

Máth, J. (1996). Linear and quadratic predictability and separability for Homogeneous bilinear time series of hermite degree two. Publicationes Mathematicae, 49(1-2), 47-58. 
Máth, J. (2004). Kategórikus változók elemzése (loglineáris modell látens változókkal). Alkalmazott Pszichológia, 6(1), 57-81.

Molenaar, I. W., \& Münnich, Á. (1993). A relation between point items and cumulative items. In Steyer, R., Wender, K. F., \& Widaman, K. F. (Eds), Psychometric Methodology. Proceedings of the 7th European Meeting of the Psychometric Society in Trier (pp. 338-342). Stuttgart: Gustav Fischer Verlag.

Münnich, Á. (1993). Probabilistic Choice Systems. In Steyer, R., Wender, K. F., \& Widaman, K. F. (Eds), Psychometric Methodology. Proceedings of the 7th European Meeting of the Psychometric Society in Trier (pp. 349-354). Stuttgart: Gustav Fischer Verlag.

Münnich, Á. (1994). Collective Choice Probabilities. In Fisher, G. H., \& Laming, D. (Eds), Contributions to Mathematical Psychology, Psychometrics, and Methodology (pp. 185-194). New York: Springer-Verlag.

Münnich, Á. (2000). A matematikai modellek szerepe a pszichológiában. Alkalmazott Pszichológia, 2(1), 57-64.

Münnich, Á. (2006). An axiomatic characterization of value judgments relative to a reference point. Mathematical Social Sciences, 51(1), 58-69.

Münnich, Á., Balázs, K., Fedor, Gy., \& Hidegkuti, I. (2001). Egyszerú (teszt-) skálaszerkesztési módszerek, Alkalmazott Pszichológia, 3(2), 65-87.

Münnich, Á., \& Hidegkuti, I. (2012). Strukturális egyenletek modelljei: oksági viszonyok és komplex elméletek vizsgálata pszichológiai kutatásokban. Alkalmazott Pszichológia, 14(1), 77-102.

Münnich, Á., Maksa, G., \& Mokken, R. J. (1999). Collective judgement: combining individual value judgements. Mathematical Social Sciences, 37(3), 211-233.

Münnich, Á., Maksa, G., \& Mokken, R. J. (2000). n-variable bisection. Journal of Mathematical Psychology, 44(4), 569-581.

Münnich, Á., Mokken, R. J., \& Saris, W. E. (2004). Testing n-stimuli bisymmetry. Journal of Mathematical Psychology, 48(6), 399-408.

Münnich, Á., Nagy, Á., \& Abari, K. (2006). Többváltozós statisztika pszichológus hallgatók számára. Debrecen: Bölcsész Konzorcium. Letöltve: 2006. 08. 02-án: http://psycho.unideb.hu/ statisztika

Münnich, Á., Nagy, Á., \& Pénzes, T. (2004). A regresszió diszkrét bája: regressziószámítás kategórikus és szegmentált változókkal. Alkalmazott Pszichológia, 6(1), 82-109.

Nagybányai Nagy, O. (2014). Pszichometriai fejlesztési lehetôségek az online tesztelésben. Alkalmazott Pszichológia, 14(1), 93-110.

Niroomand, S., Takács, Sz., \& Vizvári, B. (2011). To Lay Out or Not To Lay Out? Annals of Operation Research, 191(1), 183-192.

Rijmen, F., Tuerlinckx, F., Meulders, M., Smits, D. J. M., \& Balázs, K. (2006). Mixed model estimation methods for item response models. In Smith, E. V. Jr., \& Smith, R. M. (Eds), Rasch Measurement: Advanced and Specialized Applications (pp. 329-353). Chicago: University of Illinois Press.

Rijmen, F., Tuerlinckx, F., Meulders, M., Smits, D. J. M., \& Balázs, K. (2005). Mixed model estimation methods for the Rasch model. Journal of Applied Measurement, 6(3), 273-288.

Rózsa, S., Nagybányai Nagy, O., \& Oláh, A. (Eds) (2006): A pszichológiai mérés alapjai. Budapest: Bölcsész Konzorcium.

Surányi, Zs., Babocsay, Á., Takács, Sz., \& Vargha, A. (2011). Új klasszifikációs módszerek a személyiségpszichológiában. Pszichológia, 31(4), 317-340.

Szúcs, D., \& Ioannidis, J. (2017). When null hypothesis significance testing is unsuitable for research: a reassessment. Frontiers in Human Neuroscience, 11, 390. 
T. Kárász, J. (2019a): Hibabecslési eljárások véletlen jelenségek paramétereinek becslésére. Psychologia Hungarica Caroliensis, 7(2), 104-114.

T. Kárász, J. (2019b): Estimation methods on standard error of different statistical parameters. Psychologia Hungarica Caroliensis, 7(2), 213-220.

T. Kárász, J., \& Takács, Sz. (2020). Adaptív tesztek minimális hosszának, hibájának, értékelési szintjének és a megoldók számának összefüggései - általános megoldási aránnyal. Alkalmazott Matematikai Lapok, (megjelenés alatt).

Takács, Sz., Makrai, B., \& Vargha, A. (2015). Klasszifikációs módszerek mutatói. Psychologia Hungarica Caroliensis, 3(1), 67-88.

Takács, Sz., Kis, Gy., Makrai, B., \& Liberman, A. (2017). Tipológiákhoz tartozás varianciaanalízis alkalmazásával, LVA hangelemzés vertikális vizsgálata. Psychologia Hungarica Caroliensis, 4(2), $60-78$.

Terdik, Gy., \& Máth, J. (1998). A new test of linearity of time series based on the bispectrum. Journal of Time Series Analysis, 19(6), 737-753.

Vargha, A. (1993). How to use ANOVA in case of dichotomous dependent variables. In Steyer, R., Wender, K. F., \& Widaman, K. F. (Eds), Psychometric Methodology. Proceedings of the 7th European Meeting of the Psychometric Society in Trier (pp. 535-539). Stuttgart: Gustav Fischer Verlag.

Vargha, A. (1994). A Szondi-teszt pszichometriája. Budapest: Universitas Könyvkiadó.

Vargha, A. (1999). Két csoport összehasonlítása nemparaméteres statisztikai eljárások segítségével. Magyar Pszichológiai Szemle, 54, 567-589.

Vargha, A. (2000). Két pszichológiai populáció sztochasztikus egyenlôségének ellenôrzésére alkalmas statisztikai próbák összehasonlító vizsgálata. Magyar Pszichológiai Szemle, 55, 253-281.

Vargha, A. (2001). Érvényes-e a kétmintás $t$-próba nem normális eloszlások esetén? Pszichológia, $21(1), 83-105$.

Vargha, A. (2002). Független minták egyszempontos összehasonlítása új rangsorolásos eljárások segítségével. Statisztikai Szemle, 80(4), 328-353.

Vargha, A. (2003). Robusztussági vizsgálatok az egymintás t-próbával. Statisztikai Szemle, 81(10), 872-890.

Vargha, A. (2004). A kétszempontos sztochasztikus összehasonlítás modellje. Statisztikai Szemle, $82(1), 67-82$.

Vargha, A. (2005). Sokaságok összehasonlítása új módszerekkel. Statisztikai Szemle, 83(5), $429-448$.

Vargha, A. (2011). A parciális korrelációs együttható értelmezési problémái a többdimenziós normalitás feltételének sérülése esetén. Statisztikai Szemle, 89, 275-293.

Vargha, A. (2016a). Szignifikanciatesztek - negyven éve hibás elemzéseket végzek és téveszméket tanítok? Statisztikai Szemle, 94(4), 445-451. DOI: 10.20311/stat2016.04.hu445

Vargha, A. (2016b). A ROPstat statisztikai programcsomag. Statisztikai Szemle, 94(11-12), $1165-1192$.

Vargha, A. (2019). Többváltozós statisztika dióhéjban: változó-orientált módszerek. Budapest: Pólya Kiadó.

Vargha, A. (2020). Normális vagy? És ha nem? Statisztikai módszerek nem normális eloszlású változókkal pszichológiai kutatásokban. Budapest: Pólya Kiadó.

Vargha, A. (2021). Személy-orientált többváltozós statisztika: klasszifikációs módszerek. Budapest: Pólya Kiadó (megjelenés alatt).

Vargha, A., \& Bergman, L. R. (2012). A Method to Maximize the Information of a Continuous Variable in Relation to a Dichotomous Grouping Variable: Cutpoint Analysis. Hungarian Statistical Review, 90, Special Number 16, 101-122. 
Vargha, A., \& Bergman, L. R. (2019). MORI coefficients as indicators of a "real" cluster structure. Hungarian Statistical Review, 2(1), 3-23.

Vargha, A., Bergman, L. R., \& Delaney, H. D. (2013). Interpretation problems of the partial correlation with nonnormally distributed variables. Quality and Quantity, 47(6), 3391-3402.

Vargha, A., Bergman, L. R., \& Takács, Sz. (2016). Performing cluster analysis within a person-oriented context: Some methods for evaluating the quality of cluster solutions. Journal for Person-Oriented Research, 2(1-2), 78-86.

Vargha, A., \& Borbély, A. (2017). Új klasszifikációs módszerek alkalmazása a kétnyelvúség és az etnikai identitás kutatásában. Statisztikai Szemle, 95(8-9), 805-822.

Vargha, A. \& Delaney, H. D. (1998). The Kruskal-Wallis test and stochastic homogeneity. Journal of Educational and Behavioral Statistics, 23, 170-192.

Vargha, A., \& Delaney, H. D. (2000). A critique and improvement of the CL common language effect size statistic of McGraw and Wong. Journal of Educational and Behavioral Statistics, 25(2), 101-132.

Vargha, A., Rudas, T., Delaney, H. D., \& Maxwell, S. E. (1996). Dichotomization, partial correlation, and conditional independence. Journal of Educational and Behavioral Statistics, 21(2), 264-282.

Vargha, A., Torma, B. \& Bergman, L. R. (2015). ROPstat: a general statistical package useful for conducting person-oriented analyses. Journal for Person-Oriented Research, 1(1-2), 87-98.

\title{
MATHEMATICAL PSYCHOLOGY / PSYCHOLOGICAL STATISTICS / PSYCHOMETRICS
}

\author{
VARGHA, ANDRÁS
}

The mathematically based development of psychology in Hungary in the past 30 years can be attached primarily to the Institutes of Psychology of three universities: Debrecen University, Eötvös Loránd University, and Károli Gáspár University of the Reformed Church. The national center of mathematical psychology is the Institute of Psychology of Debrecen University, where substantial results have been obtained in the last decades with regard measurement theory and structural equation modelling. Within psychological statistics, outstanding outcomes have been published - mostly in international journals - in the topics of hypothesis testing, Bayesian statistics, reliability of parametric tests and their robust variants, ordinal methods, time series analysis, and classification analyses. In the last 30 years, some significant results can be due to the topic of psychometrics as well.

Keywords: mathematical psychology, psychological statistics, measurement theory, psychometrics

A cikk a Creative Commons Attribution 4.0 International License (https://creativecommons. org/licenses/by/4.0/) feltételei szerint publikált Open Access közlemény, melynek szellemében a cikk bármilyen médiumban szabadon felhasználható, megosztható és újraközölhetô, feltéve, hogy az eredeti szerzô és a közlés helye, illetve a CC License linkje és az esetlegesen végrehajtott módosítások feltüntetésre kerülnek. (SID_1) 